\title{
STATUS HUKUM IBU TIDAK MENYUSUI BAYI DAN SOLUSI PENCEGAHANNYA
}

\author{
Agus Nurcholis Saleh \\ Program Studi Ahwal al-Syakhsiyyah Universitas Mathla'ul Anwar Banten \\ Jl. Ki Mas Abdurrahman, Cikaliung, Saketi, Pandeglang \\ e-mail: guscholis@gmail.com
}

\begin{abstract}
Much research has been done on breast milk. The results are significant. But the rate of early breastfeeding and exclusive breastfeeding is still far from expectations. Moreover, modernization and globalization have succeeded in encouraging women to work. The term, career woman. Unfortunately, the woman forgot her nature as the only supplier of ASI. Be, many babies whose rights are not fulfilled. This study relates the ASI significance, including the legal status for women who leave ASI. This study method is literature. The author collects literature on ASI, and legal consequences for those who "intentionally" leave their breastfeeding obligations. The author reads the Qur'an as the main source of analysis. The previous research report became the validation of the main source. This study is written descriptively with the deductive method. This research produced three things. First, they are treacherous towards the mandate of Allah SWT. Second, there are three inherent statuses for mothers who refuse to breastfeed: betrayal, destruction, and debt. Third, the husband must guide his wife to prepare berself as best as possible in the face of pregnancy, birth, and breastfeeding, so that the duties and mandates are realized.
\end{abstract}

Kata kunci: ASI, debt, betrayal, destroyer

\section{PENDAHULUAN}

$\mathscr{D}$ i masa modern sekarang ini, isu gender dan emansipasi wanita menjadi arus yang sulit dibendung. Batasbatas kehormatan wanita menjadi sumir, terdegradasi arus globalisasi. Segala yang mengekang wanita, dianggap tidak pantas untuk diterapkan. Padahal tidak semua wanita merasa harus global, sebagaimana banyak wanita merasa senang dijajah oleh modernitas. Jadilah sebuah istilah, "wanita karir", menjadi incaran para wanita untuk bergabung dalam kelompok sosialita.

Hari ini, mudah kita saksikan, banyak wanita yang berani mengalahkan laki-laki. Ada wanita menjadi sopir, bahkan menjadi kondektur angkutan umum. Ada wanita menjadi tukang parkir. Ada wanita menjadi kuli bangunan. Sepak bola wanita sedang digaungkan. Sedikit demi sedikit menuju tinju, kemudian merasa gagah tampil dalam tarung bebas beladiri. Penulis tidak tahu apa yang sedang mereka kejar. Alasan gender dan emansipasi memaksa laki-laki untuk pandai beradaptasi.

Akumulasi dari anomali di atas adalah (memaksa) pemufakatan kemuliaan dengan pangkat dan jabatan dunia. Ada banyak wanita yang harus menjadi modern. Salah satunya dengan membenci domestifikasi. Aturan-aturan dianggap sebagai belenggu. Ada wanita 
yang bersemangat sekali untuk bertarung dalam persaingan. Bahkan jika perlu, dengan sengaja menyalip suaminya. Mereka adalah wanita-wanita yang lupa bahwa suaminya tidak mungkin menyusui anak-anaknya.

Ada banyak suami yang sanggup bertukar peran, yaitu dengan menjadi Bapak Rumah Tangga. Mereka rela saja menerima, demi keutuhan keluarga. Lakilaki sudah biasa menjadi ojeg bagi istrinya, kecuali berimplikasi pada kepemimpinan keluarga. Tidak masalah bagi suami untuk mencuci piring dan pakaian, atau jika harus membersihkan rumah dan halamannya. Demikian pula memasak. Tapi dari pertukaran peran ini, ada dua hal yang tidak sanggup digantikan suami, itulah mengandung dan menyusui.

Ketika banyak wanita beraktivitas di ruang publik, kedua tugas special itu menjadi terabaikan. Waktunya menjadi hak publik, sementara anak-anaknya menjadi prioritas cadangan. Padahal, tugas itu tidak tergantikan. Amanah itu bukan suami yang menjadikan. Tapi Allah yang menetapkan. Jadilah status ibu tidak tercapai karena tugas utamanya tidak dilaksanakan. Awalnya ingin menunda kehamilan, semakin lama akan tersiksa dengan kebutuhan. Menunda itu keinginan, sedangkan cerianya anak adalah kebutuhan.

Hari ini, belum ada tawaran untuk penggantian media hamil. Bayi tabung pun tetap dikembalikan ke rahim perempuan. Dengan demikian, tidak boleh tidak, wanita "terpaksa" harus menerima. Sedangkan untuk kewajiban menyusui, banyak wanita mulai berpaling ke Bank ASI atau ibu susuan. Bahkan, modernitas telah memberanikan wanita untuk tidak menjadi ibu. Katanya, ada susu pengganti ASI yang dengan mudah bisa dibeli. Mereka berasumsi, mencari uang untuk beli susu pengganti, berarti tugas sudah dilunasi.

Kejadian itu memunculkan indikasi sederhana bahwa banyak wanita yang tidak naik kelas menjadi ibu. Padahal Allah telah menetapkan perjalanan itu untuk kemuliaan. Menikah adalah pemenuhan kebutuhan lahir dan batin seorang wanita. Setelah itu, menjadi ibu adalah konsekuensi yang mulia. Sebagai ibu, ia dipercaya untuk mendistribusikan ASI kepada bayinya. Peralihan airsusu yang ada di payudaranya adalah hak dan kewajiban antara dia dengan bayinya. Sejatinya, berbahagialah menjadi hamba yang dipercaya.

Di Pandeglang, saya melihat banyak wanita yang tidak merasa telah menjadi ibu, meski sudah dihadiahi keturunan. Mereka memilih "lari" dari tanggung jawab untuk mengejar "sedikit" materi. Anak bayinya ditinggalkan bersama ibunya, nenek dari bayinya. Padahal bayinya sangat membutuhkan asupan ASI. Tidak ada satu pun yang bisa menggantikan posisi ASI untuk sang bayi. Lebih celaka lagi, nenek si bayi merelakan anaknya pergi, demi sesuap nasi. Keduanya berkontribusi atas perginya kesempurnaan dari sang si bayi.

Sungguh, ucapan sang nenek itu tidak benar-benar rela. Dia hanya terpaksa. Dia khawatir dan takut dengan pemenuhan kebutuhan anak cucunya. Kalau tidak ada yang bekerja, mereka akan makan apa. Akhirnya, dipilihlah cucu untuk tinggal dan dirawat olehnya, meski repot menjadi teman setia. Namun dia lupa, kepergian anaknya telah meninggalkan utang yang takkan 
sanggup dibayarnya, meskipun penghasilan telah berhasil membuatnya kaya. Setelah 2 tahun terlewati, bayinya sudah tidak lagi membutuhkan ASI.

Menurut Menteri Kesehatan (20/8), masih banyak ibu-ibu yang belum memberikan hak ASI pada anak. Di tahun 2017, angka pemberian ASI eksklusif, hanya 35,7 persen. Semoga angka itu lebih karena banyaknya ibu-ibu menyusui yang tidak menjadi sasaran survey. Meskipun angkanya naik, tapi masih mengkhawatirkan dan jauh dari harapan. Pada tahun 2016, pemberian ASI eksklusif hanya 29,5 persen. Angka di atas terbilang sangat kecil jika mengingat pentingnya peran ASI bagi kehidupan anak.

Di dunia, telah ada organisai Global Breastfeeding Collective, kerjasama lebih dari 20 lembaga internasional dan organisasi non-pemerintah yang focus kegiatannya mempromosikan ASI Eksklusif. Kelompok kerjasama itu dikoordinir oleh UNICEF dan WHO. Mereka berkomitmen dalam membantu anak-anak untuk tumbuh kembang secara baik, mencegah kekurangan nutrisi, mempertahankan kecerdasan otak, dan mengurangi resiko obesitas pada anak ("www.who.int," n.d.).

Di Indonesia, angka inisiasi menyusui dini (IMD) tahun 2017 di level 57,8 persen. Angka itu masih jauh dari target Kementerian Kesehatan sebesar 90 persen (Juniman, 2018). Inisiasi menyusu dini adalah meletakkan bayi secara tengkurap di dada atau perut ibu sehingga kulit Bayi melekat pada kulit ibu. Inisiasi ini paling singkat selama 1 (satu) jam. Maksudnya untuk memberikan kesempatan kepada bayi agar dapat mencari puting susu ibu dan menyusu sendiri (Peraturan Pemerintah No. 33 Tahun 2013 tentang Pemberian Air Susu Ibu Eksklusif., 2013).

Di dunia, hanya dua anak (dari lima kelahiran) yang mendapatkan inisiasi dini untuk menyusui. Demikian pula dengan bayi yang mendapatkan ASI eksklusif, hanya 40 persen ("www.who.int," n.d.). Dengan demikian, ibu-ibu harus mengakui bahwa mereka berutang ASI kepada anak-anaknya. Di dunia, termasuk Indonesia, sebanyak 60 persen ibu-ibu berhutang ASI kepada anak-anaknya. Di Indonesia, ibu yang berutang ASI eksklusif kepada bayinya sebanyak 64,3 persen. Sedangkan yang berutang menyusui dini sebanyak 42,2 persen.

Manfaat ASI demikian nyata. Anak bayi akan terjaga kesempurnaannya, dimana ASI menjadi pondasi kehidupannya. Sejak keluar dari rahim ibunya, bayi akan mencari sumber baru bagi kelanjutan hidupnya. Itulah dekapan kasih sayang ibu bersama ASI di dalam mulutnya. Ibu-ibu pembawa ASI pun banyak mendapatkan manfaat. Mereka akan terhindar dari potensi kanker payudara. Sayang, entah ibu-ibu yang tidak tahu, ataukah ibu-ibu tidak menyadarinya, karena banyak anak-anak tidak mendapatkan haknya.

Berdasarkan permasalahan di atas, kajian ini akan fokus pada tiga masalah: pertama, menelaah ASI sebagai asupan pertama dan utama bagi bayi. Kedua, menggali hukum ibu-ibu yang melalaikan tugasnya sebagai distributor ASI. Ketiga, tawaran solusi bagi pihak-pihak terkait dalam kasus utang ASI, supaya tidak terjadi lagi kejadian yang sama di masa yang akan datang. 
Dari fokus masalah tersebut, penulis akan menggambarkan ASI secara komprehensif sebagai hak bayi yang tidak tergantikan. Kemudian, penulis akan menjelaskan hukum syar'i bagi ibu-ibu yang tidak amanah dalam ASI dan bayi. Setelah itu, penulis akan merumuskan langkah-langkah solutif dalam rangka kemaslahatan bayi dan ibunya dalam hal ASI. Kajian ini penulis beri judul: "Status Hukum Ibu Tidak Menyusui Bayi dan Solusi Pencegahannya".

\section{METODE PENELITIAN}

Kajian ini bersifat kualitatif, karena akan menghasilkan data deskriptif berupa kata-kata tertulis atau lisan dari orangorang dan perilaku yang diamati (L.J Moleong, 2011: 4). Adapun metode utama dalam penelitian ini adalah library research. Kepustakaan menjadi bagian (model) dalam penelitian karena data-data atau bahan-bahan yang diperlukan dalam menyelesaikan penelitian berasal dari perpustakaan, baik berupa buku, ensiklopedi, kamus, jurnal, dokumen, majalah, dan lain sebagainya (Harahap, 2014: 68-74).

Tinjauan pustaka membantu peneliti untuk melihat ide-ide, pendapat, dan kritik tentang topic tersebut yang sebelumnya dibangun dan dianalisis oleh para ilmuwan sebelumnya (J.R. Raco, 2010: 104). Penyusun akan banyak "berbicara" atau "berdialog" dengan buku-buku, arsip-arsip, dokumendokumen tua, jurnal, catatan-catatan, dokumentasi film-fotografi, monografi, dokumentasi statistic, diaries, surat-surat, dan lain-lain (B.A Simanjuntak dan Soedjito Sosorodiharjo, 2014: 8).
Dalam kajian ini, penulis akan berdialog dengan banyak dokumen tentang Air Susu Ibu dan hukum syar'i bagi yang meningalkan kewajibannya menyalurkan ASI. Selain al-Qur'an dan hadits sebagai panduan utama, ada beberapa jurnal dan buku yang ditelaah untuk mendukung pengambilan kesimpulan penelitian. Dalam hal ini, status hukum ibu akan ditentukan dari dukungan beberapa literature tersebut.

\section{LANDASAN TEORITIK}

ASI adalah vaksin pertama bayi sejak lahir. ASI menyediakan antibodi yang penting dan menjadi factor kekebalan bagi bayi. Dalam proses awal kelahiran bayi, ASI menjadi pembeda antara hidup dan mati. Satu jam setelah kelahiran adalah titik kritis bayi, apakah sigap dengan ASI ("www.who.int," n.d.), ataukah memiliki masalah yang disebut dengan "bingung puting" (N. Yuliarti, 2010: 2). Meskipun bayinya hidup, tapi jika terlewatkan momen inisiasi menyusui dini, ada yang berasumsi bahwa bayi hidup dalam mati (newborn deaths).

Tidak ada yang meragukan bahwa Air Susu Ibu adalah nutrisi terbaik bagi bayi. ASI mengandung semua gizi yang dibutuhkan untuk membangun dan menyediakan energi bagi pertumbuhan dan perkembangan bayi secara optimal. Di dalam ASI terkandung zat-zat gizi yang diperlukan bayi untuk pertumbuhan dan mengandung zat-zat kekebalan yang sangat penting untuk mencegah timbulnya penyakit, serta mudah dicerna oleh pencernaan bayi. Dengan demikian ASI adalah makanan terbaik bagi bayi, oleh karena itu setiap bayi harus 
memperoleh ASI (Departemen Kesehatan RI, 1991: 45).

Disamping itu, ASI mengandung beberapa zat anti terhadap penyakitpenyakit yang keberadaannya tidak diberikan melalui jalan lain. ASI merupakan sebuah asupan paling penting untuk bayi dibawah umur 2 tahun (Prawira). Menurut catatan WHO, pemberian ASI bagi bayi dapat menyelamatkan 823,000 anak balita setiap tahun. Dalam kondisi darurat, misalnya di masyarakat yang kesulitan akses terhadap air bersih dan pelayanan dasar kesehatan, ASI menjamin keselamatan, nutrisi, dan sumber makanan yang mudah dikonsumsi oleh anak-anak, sekaligus melindungi mereka dari penyakit (“www.who.int," n.d.).

Bayi sampai usia 6 bulan, tidak membutuhkan asupan kecuali air susu dari ibunya. Bayi tidak perlu diberi apaapa, kecuali makanan yang langsung diproduksi oleh ibu. Itulah yang dikenal dengan ASI Eksklusif. Kebutuhan nutrisi bayi sampai usia 6 bulan dapat dipenuhi hanya dengan memberikan air susu ibu saja. Makanan terbaik untuk bayi, dengan nutrisi terbaik, telah dicukupkan melalui ASI (N. Yuliarti, 2010: 1). Kandungan yang terdapat dalam ASI antara lain: Kolostrum, Laktosa, Protein, Taurin, Lemak, Mineral, Vitamin, dan zat Kekebalan (Munasir).

ASI memiliki kekebalan dari berbagai mikro-organisme yang membantu melindungi bayi dari serangan penyakit. Hal itu didukung oleh ragam vitamin yang melekat pada ASI, yaitu vitamin A, B (asam folat), C (pelarut), D (tulang), E, dan $\mathrm{K}$ (faktor pembeku). Vitamin A berfungsi untuk kesehatan mata, untuk mendukung pembelahan sel, kekebalan tubuh, dan pertumbuhan. Sedangkan vitamin E untuk ketahanan dinding sel darah merah.

ASI mengandung $1,6 \%$ albuminoidal, 0,4\% lemak, 3,8\% gula, garam, dan beberapa vitamin. Kandungan tersebut hanya terdapat dalam ASI, dan tidak terdapat pada yang lain, baik susu formula maupun susu sapi atau kambing (A.H Abdullah, 1993: 32). Bayi yang tidak segera mendapatkan ASI setelah kelahirannya atau tidak diberikan MP-ASI secara dini akan lebih mudah terkena infeksi saluran pencernaan dan pernafasan, mudah terkena alergi serta intoleransi susu formula (I.K.A. Mataram, 2011: 37-48).

Selain vitamin, kekuatan ASI ada pada kolostrum, yaitu ASI yang keluar pada hari pertama dan kedua setelah melahirkan. Warnanya kekuningkuningan dan lebih kental, lebih banyak mengandung protein dan vitamin berfungsi untuk melindungi bayi dari penyakit infeksi. Zat lain adalah Laktosa, yaitu karbohidrat utama dalam ASI dan berfungsi sebagai salah satu sumber untuk otak. Jumlahnya meningkat terutama pada ASI transisi (7-14 hari setelah melahirkan). Adapun protein ASI mudah diserap oleh usus bayi dibandingkan dengan susu formula.

Air Susu Ibu yang keluar dari kelenjar susu ibu pada dasarnya dapat dibagi menjadi tiga macam ASI berdasarkan waktu keluarnya serta kandungan zat gizinya. ASI yang keluar pertama kali setelah ibu melahirkan disebut kolostrum. Setelah kolustrum tidak keluar lagi, ASI disebut sebagai ASI masa transisi dan setelah masa itu 
tepatnya 10 hari kelahiran ASI disebut ASI matang/ASI dewasa. ASI yang pertama keluar disebut dengan foremilk dan selanjutnya disebut dengan hindmilk. Fore milk merupakan ASI awal yang banyak mengandung air, sedangkan hind milk lebih banyak mengandung karbohidrat dan lemak (U. Roesli, 2005: 22).

Kemudian, ASI dilengkapi juga dengan taurin, yaitu zat putih telur yang hanya terdapat pada ASI. Fungsinya sebagai neuro transmitter dan berperan penting untuk proses maturasi sel otak. Lemak berfungsi untuk pertumbuhan otak bayi. Kandungan lemak dalam ASI sekitar $70-78 \%$. Zat besi dan kalsium di dalam ASI merupakan mineral dan jumlahnya tidak terlalu banyak dalam ASI. Mineral ini berfungsi sebagai pembentukan atau pembuatan darah dan pembentukan tulang (Soetjiningsih, 1997: 25).

Berbicara tentang ASI tak luput dari fisiologi Laktasi, karena menyusui merupakan proses yang cukup kompleks. Laktasi atau menyusui mempunyai dua pengertian yaitu produksi ASI dan pengeluaran (Ariani, 2009: 58). ASI diproduksi saatsaat hamil, dimulai dengan meningkatnya hormon prolaktin. Saat hamil, ASI masih terhambat oleh kadar estrogen yang begitu tinggi. Namun, saat melahirkan (+3), kadar estrogen dan progesterone turun drastis sehingga pengaruh prolaktin lebih besar. Saat itulah ASI bisa dikeluarkan. Mekanisme ini akan optimal dalam waktu sekitar 72 jam setelah melahirkan, termasuk perangsangan putting susu, sehingga pembuatan ASI semakin lancar.

Pengeluaran air susu dari payudara adalah faktor penting dalam kelanjutan produksinya, terdapat bahan kimia dalam
ASI yang dirancang untuk menghentikan produksi ASI jika tidak digunakan, jika ASI yang sudah diproduksi tidak diisap atau dikeluarkan dari payudara dalam waktu yang lama, bahan kimia (penghambat) atauinhibitor autokrin ini akan menghentikan sel-sel pembuat ASI memproduksi ASI. Intensitas yang tinggi pada bayi untuk menyusu maka semakin banyak ASI diproduksi, sebaliknya jika semakin jarang bayi untuk menyusu makin sedikit payudara menghasilkan ASI (M. Biancuzzo, 1999: 115). Isapan bayi pada payudara akan merangsang hormon prolaktin dan oksitosin untuk menstimulus produksi ASI (M.J. Hockenberry and David Wilson, 2015: 277, $694,740,1125)$.

Memberi ASI kepada bayi adalah cara terbaik untuk menyediakan nutrisi yang dibutuhkan bayi. WHO merekomendasikan bahwa setiap ibu harus mulai memberikan ASI ekslusif sejak satu jam setelah melahirkan sampai usia bayi 6 bulan. Penelitian di Filipina menegaskan tentang manfaat pemberian ASI eksklusif dan dampak negatif pemberian cairan tambahan tanpa nilai gizi terhadap timbulnya penyakit diare. Seorang bayi yang diberi air putih, teh, atau minuman herbal lainnya akan berisiko terkena diare 2-3 kali lebih banyak dibanding bayi yang diberi ASI Eksklusif (N. Yuliarti, 2010: 32).

ASI adalah penolong bagi bayi-bayi yang prematur $(<1500 \mathrm{~g})$ dan membutuhkan suplementasi. ASI juga menolong bayi yang berisiko hipoglikemia karena gangguan adaptasi metabolic atau peningkatan kebutuhan glukosa. ASI membantu bayi yang beresiko kehilangan cairan akut (misal karena fototerapi untuk penyakit kuning) 
dan menyusui serta memerah ASI belum bisa mengimbangi kebutuhan cairan.

Demikian pentingnya ASI dan pemberian ASI, WHO memberi perhatian khusus. Setiap tahun, di tanggal 1-7 August, WHO mengadakan acara World Breastfeeding Week, sebuah agenda tahunan untuk mendorong (kampanye) pemberian ASI dan meningkatkan kesehatan bayi di seluruh dunia. Hal itu dalam rangka memperingati sebuah deklarasi yang ditandatangani pada bulan Agustus 1990 oleh petinggi pemerintahan, WHO, UNICEF dan organisasi lain, untuk melindungi, mempromosikan dan mendukung pemberian ASI (http://www.who.int/mediacentre/even ts/2016/world-breastfeeding-week/en/ n.d.).

WHO mengajak semua orang untuk mendukung ibu-ibu memberikan ASI kepada bayinya kapanpun, dimanapun, termasuk memberikan kesempatan seluas-luasnya kepada semua untuk mendukung pemberian ASI. Hal ini mengingat "distribusi yang tidak terkendali dan penggunaan susu formula bayi dalam situasi darurat seperti ini - di mana ada tantangan air dan sanitasi yang serius dan resiko penyakit lainnya sangat berbahaya. Mendukung pemberian ASI adalah salah satu hal yang paling penting untuk dilakukan dalam melindungi bayi.

UNICEF dan WHO memprioritaskan perlindungan, promosi dan dukungan menyusui sebagai tindakan yang menyelamatkan jiwa untuk bayi di manamana, dan terutama dalam keadaan darurat. Selama situasi darurat, penyakit dan tingkat kematian di kalangan bayi dan anak-anak lebih tinggi daripada kelompok usia lainnya, dan lebih muda anak tersebut, semakin tinggi juga risikonya, terutama bayi di bawah enam bulan yang paling rentan. Bayi yang minum susu formula dibuat dengan air yang terkontaminasi dengan kuman atau diberikan dengan botol tidak steril atau dot, bisa menjadi sangat sakit dengan diare dan dapat meninggal dunia dalam hitungan jam.

Dengan demikian, panduan Allah tentang kewajiban memberikan ASI mendapatkan validasinya. Apalagi, ASI tidak hanya memenuhi asupan materi atau fisik semata. Lebih dari itu, melalui ASI, terbina pula kontak bathin (psikis) antara si bayi dengan ibunya.

Mari kita dalami firman Allah dalam Alqur'an [2]: 233 berikut ini:
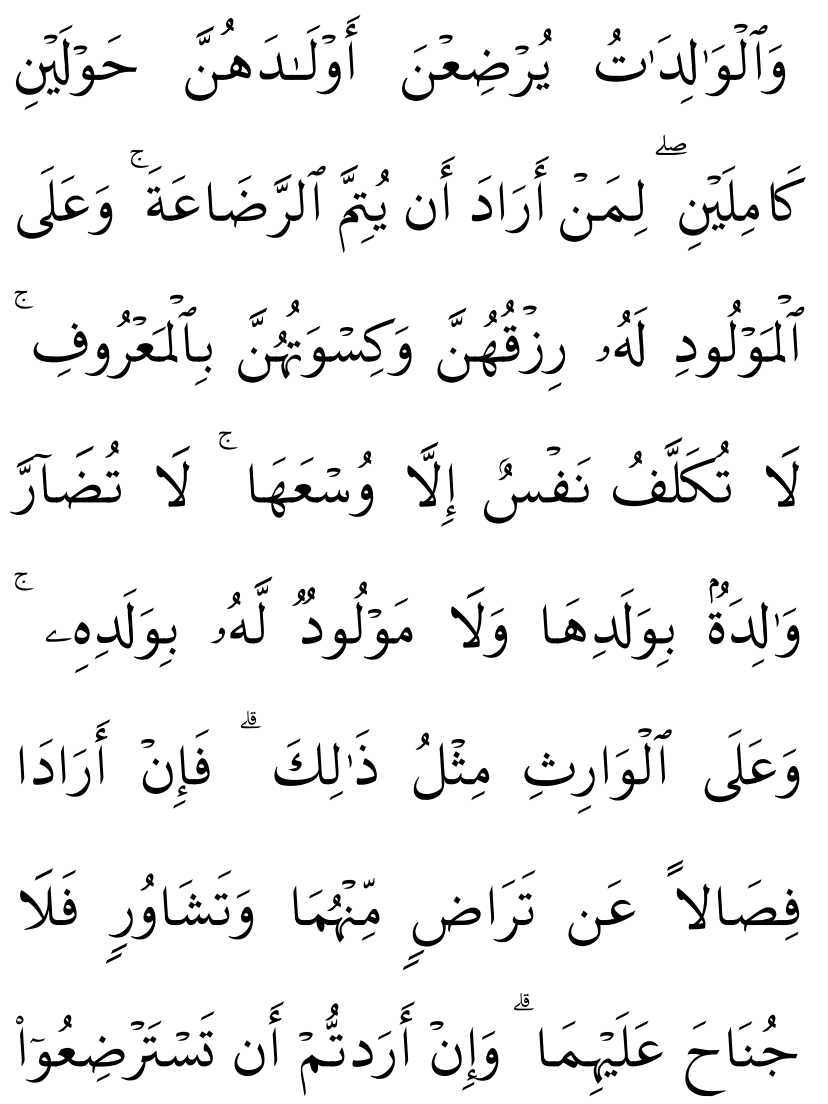

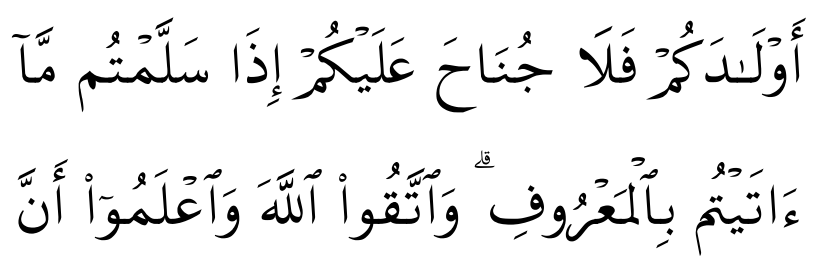

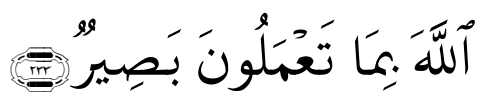

"Para ibu hendaklah menyusukan anakanaknya selama dua tahun penuh, Yaitu bagi yang ingin menyempurnakan penyusuan. Dan kewajiban ayah memberi Makan dan pakaian kepada Para ibu dengan cara ma'ruf. Seseorang tidak dibebani melainkan menurut kadar kesanggupannya. Janganlah seorang ibu menderita kesengsaraan karena anaknya dan seorang ayah karena anaknya, dan warispun berkewajiban demikian. Apabila keduanya ingin menyapih (sebelum dua tahun) dengan kerelaan keduanya dan permusyawaratan, Maka tidak ada dosa atas keduanya. dan jika kamu ingin anakmu disusukan oleh orang lain, Maka tidak ada dosa bagimu apabila kamu memberikan pembayaran menurut yang patut. Bertakwalah kamu kepada Allah dan ketahuilah bahwa Allah Maha melihat apa yang kamu kerjakan."(Al-Kalam, 2009).

Ayat di atas mengingatkan kita untuk memperhatikan hak bayi terhadap air susu ibunya. Sang ibu tidak boleh menghindar dari kewajibannya memberikan ASI. Orang tua hanya lepas dari tuntutan jika bayinya telah mendapatkan haknya, baik dari ibu kandungnya, atau ibu susuannya.

Allah juga berfirman dalam Alqur'an [31]: 14 berikut ini:

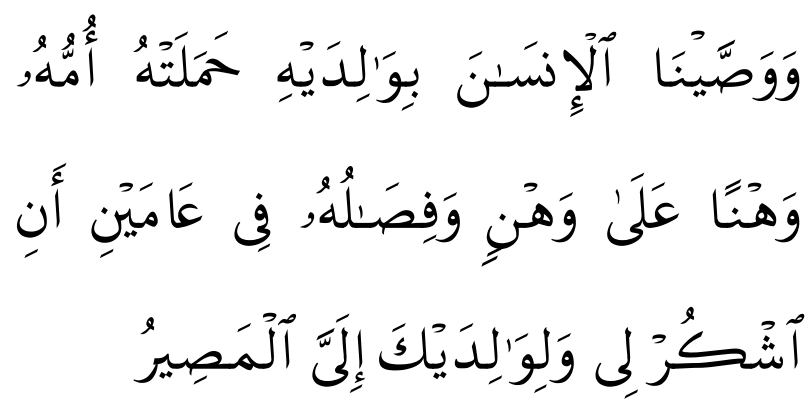

"dan Kami perintahkan kepada manusia (berbuat baik) kepada dua orang ibubapanya; ibunya telah mengandungnya dalam Keadaan lemah yang bertambahtambah, dan menyapihnya dalam dua tahun. Bersyukurlah kepadaku dan kepada dua orang ibu bapakmu, hanya kepadaKulah kembalimu" (Al-Kalam, 2009).

Allah juga mengulang lagi "kewajiban" penyusuan tersebut dalam Alqur'an [46]: 15 berikut ini:

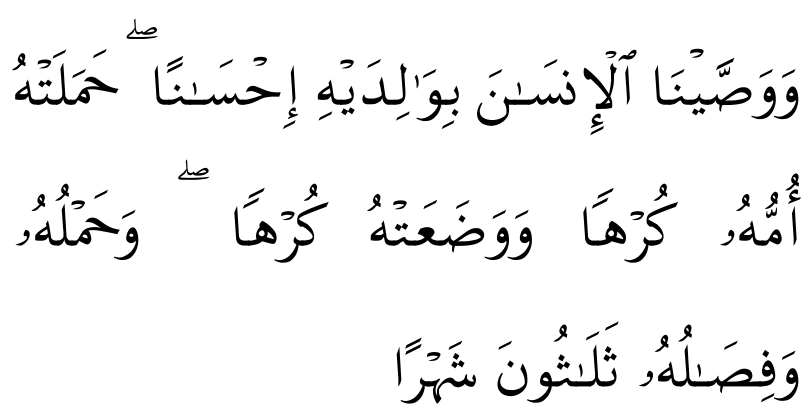

"Kami perintahkan kepada manusia supaya berbuat baik kepada dua orang ibu bapaknya, ibunya mengandungnya dengan susah payah, dan melahirkannya dengan susah payah (pula). mengandungnya sampai menyapihnya adalah tiga puluh bulan, sehingga apabila Dia telah dewasa dan umurnya sampai empat puluh tahun" (Al-Kalam, 2009).

Tiga ayat di atas menjadi tuntunan pentingnya ASI bagi bayi. Wajib bagi ibunya untuk memenuhi kebutuhan ASI bayinya. Ayahnya harus ikut mendukung 
supaya bayi mendapatkan haknya. Ketika istrinya mengalami kedaruratan, yang menyebabkan hak ASI bayi tidak terpenuhi, ia harus mencari ibu susuan yang memenuhi persyaratan dan bersedia menjadi pengganti. Ketiadaan ASI dari ibunya harus diganti dengan ASI, meskipun melalui ibu pengganti. Itulah pentingnya ASI sebagai syari'at kehidupan bayi.

Untuk menjadi contoh, Allah jalankan skenario itu dalam kisah Rasulullah, padahal kisah ini lebih dahulu datang dibandingkan ayat al-Qur'an. Meskipun disebut zaman Jahiliyyah, Muhammad lahir dalam tradisi ASI yang baik. Arab pada masa itu, ada tradisi mencari wanita-wanita yang mau menyusukan anak-anak mereka di daerah pedalaman. Maksudnya supaya kelak anak-anak itu umbuh menjadi orang yang mulia. Mereka mempunyai anggapan bahwa wanita pengasuh di kota itu pemalas lagi kurang tekun (M.Kh Bek, 1989: 9).

Salah satu kabilah di masa itu, yang kaum wanitanya menjadi ibu susuan adalah Bani Sad ibn Bakr. Sebagai anak yatim, Muhammad kecil tidak ada yang melirik. Hal yang sama berlaku kepada Halimah binti Dzuaib al-Sa'diyah. Sebagai wanita yang kurang mampu, ibu-ibu pemilik anak pun tidak menghiraukannya. Allah Yang Kuasa mempertemukannya, "Biarlah aku pergi kepada anak yatim itu dan akan kubawa. Aku tidak senang pulang bersama temanteman tanpa membawa seorang bayi" (Muhammad Haikal, 1993: 50).

Halimah menyusui Muhammad selama dua tahun. Pada masa itu, Halimah merasa mendapat berkah.
Ternak kambingnya gemuk-gemuk dan susunya pun bertambah. Allah memberkati semua yang ada padanya. Dua tahun tinggal di sahara, menikmati udara pedalaman yang jernih dan bebas, tidak terikat oleh sesuatu ikatan jiwa, juga tidak oleh ikatan meteri. Setelah dirasa cukup dan tiba masanya disapih, Muhammad dibawa ke Makkah untuk diserahkan kepada ibunya (Muhammad Haikal, 1993: 51).

Dari pemaparan di atas, ASI menjadi tanda kesempurnaan. Hal itu ditegaskan dalam ayat, "bagi yang ingin menyempurnakan". Allah tidak akan membebani seseorang dengan sesuatu yang tidak mungkin dipikulnya, melainkan sesuai dengan kesanggupannya. Supaya yakin, Allah tuntun do'anya, "Ya Tuhan kami, janganlah Engkau Pikulkan kepada kami apa yang tidak sanggup kami memikulnya" (Q.S. AlBaqarah [2]: 286). Allah juga tidak akan membebani seseorang melainkan (sesuai) dengan apa yang Diberikan Allah kepadanya (Q.S. At-Talaq [65]: 7).

Dengan demikian, tidak ada alasan untuk mengabaikan kewajiban ini, atau pura-pura tidak sanggup dengan alasan darurat. Bahkan, Allah bantu proses pemenuhan ASI itu melalui shalat. Gerakan qiyam dan takbiratul ihram (dalam shalat) merupakan bentuk meditasi yang sempurna. Gerakan tersebut akan mengurangi ketegangan dan melahirkan relaksasi. Keadaan ini akan memperlancar peredaran darah dan merangsang pengeluaran hormone prolaktin yang akan merangsang pengeluaran ASI (E.M. Sitompul, 2014: 115). Shalat juga mendidik ibu untuk tetap tenang. Siapa ibu yang kesal, misal karena 
bayi menangis, itu dapat mengganggu proses laktasi (N. Yuliarti, 2010: 35).

\section{PEMBAHASAN}

ASI adalah satu-satunya jawaban atas laparnya anak, "susuan itu karena kelaparan" (M.H.M. al-Qusyairy, n.d: 170). Ketika keluar dari rahim ibunya, bayi akan mencari kelanjutan nutrisinya. Paramedic harus sigap untuk menangkupkan bayi ke dada ibunya, paling tidak selama satu jam. Si bayi (mulutnya) dituntun ke puting susu ibunya untuk belajar dan berlatih menyusu. Secara medis, proses ini dikenal dengan inisiasi menyusui dini. Di Indonesia, angka IMD masih jauh dari harapan, dan itu harus menjadi perhatian semua pihak.

Allah memerintahkan orang tua untuk memenuhi hak ASI anak, apapun kondisinya. Alasan kedaruratan adalah alasan kebodohan, karena sebelumnya tidak merumuskan langkah-langkah persiapan (Q.S. [59]: 18). Pengecualian hanya bagi yang telah terjadi, seperti ibuibu yang terjangkit penyakit berbahaya, seperti AIDS, HIV, Harpes, dan sebagainya. Atau bagi ibu yang mengalami kelainan payudara, riwayat operasi pada payudara, atau jaringan payudara yang tidak berkembang.

Jika ayah-ibu bayi telah mempersiapkan sejak dini, bahkan jauh hari sebelum menikah, tidak akanada fase kedaruratan, karena segala kemungkinan telah dirumuskan. Ketika suami-istri sudah mempersiapkan diri, bayinya akan tetap mendapatkan ASI, meskipun bukan dari ibu kandungnya. Keduanya telah mempersiapkan ibu susuan, misalnya dari kemungkinan terburuk, bayi yang ditinggal mati oleh ibunya. Bisa juga dengan kontak teman-teman atau komunitas yang bersedia menjadi donor ASI.

Allah memahami hal itu bisa saja terjadi. Oleh karena itu, Allah mengatur, "jika kamu menemui kesulitan, maka perempuan lain boleh menyusukan (anak itu) untuknya." Ketika sudah terjadi perceraian, jangan sampai hak ASI terganggu. Suami diperintahkan untuk, "Tempatkanlah istri di mana kamu tinggal, janganmenyusahkan (menekan) istri. Jikaistriyang ditalak itu sedang hamil, berimereka nafkahnya sampai melahirkan. Jika mereka bersedia menyusukan, berilah imbalan atas jasanya" (Q.S. At-Talaq [65]: 6).

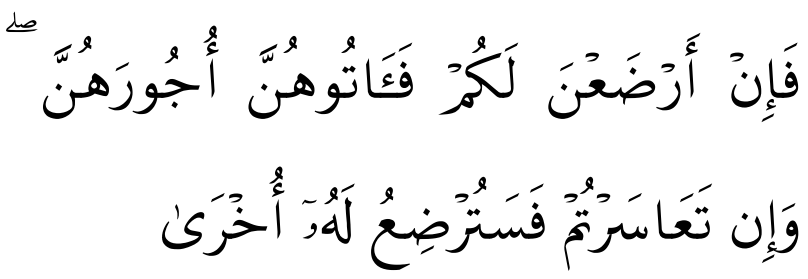

Bagi bayi, ASI tidak sekadar menghilangkan kebutuhannya, juga membantu pertumbuhan fisiknya. Menurut Ibnu Mas'ud, ASI membuat tulang menjadi kuat dan menumbuhkan daging. Hal itu hanya terjadi pada manusia di usia pertumbuhan, yaitu sewaktu masih bayi. Ibnu Mas'ud mengutip dari Nabi saw., dengan ungkapan الْعَظَْ أَنْشَزَ (A.D.S. al-Sijistany, n.d: 222). Oleh karena itu, sempurnakanlah masa penyusuan selama dua tahun karena pada masa ini bayi membutuhkan susu (W. az-Zuhaili, 2013: 568). Menurut Jumhur, Q.S. Al-Baqarah [2]: 233 menegaskan penyusuan secara sempurna, dua tahun.

Dengan demikian, status ibu-ibu yang tidak bersedia memberikan ASI kepada bayinya adalah khianat. Ini adalah 
status yang pertama. Penegasan itu bisa dipahami dari firman-Nya, "Wahai orangorang yang beriman! Janganlah kamu mengkhianati Allah dan Rasul dan (juga) janganlah kamu mengkhianati amanat yang dipercayakan kepadamu, sedang kamu mengetahui" (Q. S. Al-Anfal [8]: 27). Kelahiran anak dan konsekuensi pengasuhannya adalah bagian dari ujian hidup (Q. S. Al-Anfal [8]: 28). ASI adalah bagian dari ujian tersebut, apakah ibunya naik tingkat karena lulus ujian, atau berkhianat.

Sejak di alam ruh, kita sudah tahu bahwa kita telah bersaksi, "Dan (ingatlah) ketika Tuhan-mu Mengeluarkan dari sulbi (tulang belakang) anak cucu Adam keturunan mereka dan Allah Mengambil kesaksian terhadap roh mereka (seraya Berfirman), "Bukankah Aku ini Tuhan-mu?" Mereka menjawab, "Betul (Engkau Tuhan kami), kami bersaksi." (Kami Lakukan yang demikian itu) agar di hari Kiamat kamu tidak mengatakan, "Sesungguhnya ketika itu kami lengah terhadap ini" (Q. S. Al-A'raf [7]: 172).

Ayat itu pemberitahuan kepada para ibu, sekaligus kepada suaminya, untuk tahu konsekuensi terhadap kepercayaan yang telah diberikan. Itulah sebabnya perintah pertama kepada manusia adalah membaca (Q.S. Al-Alaq [96]: 1 - 5). Perintah ini memberi manfaat yang besar bagi manusia untuk tidak bodoh dan hidup dalam kegelapan. Jika ibu (istri) benar-benar tidak tahu, wajib bagi suami untuk memberitahu, karena posisi suami itu pelindung bagi istri (Q.S. An-Nisa' [4]: 34). Keteledoran suami dalam menjaga istri, sama dengan bersiap-siap untuk masuk ke dalam siksa (Q.S. At-Tahrim [66]: 6).
Sebagai imam dalam keluarga, suami (laki-laki) harus memimpin istri ke jalan yang benar dengan cara yang benar. Laki-laki harus menyadari nikmat Allah atas kelebihan yang diberikan kepadanya dibanding perempuan. Oleh karena itu, suami tidak hanya memberi nafkah dari segi harta, tapi dalam perlakuan dan bahasa. Allah telah mewajibkan kepada suami untuk menggauli istrinya dengan baik.

Dalam kasus ASI, suami wajib rembug dengan istri sejak dini, sebelum masalah terjadi. Apalagi bagi yang istrinya memiliki aktivitas sendiri, dan ternyata penghasilan istrinya melebihi dirinya. Rumus dari Allah: "Untuk mendapatkan perempuan yang saleh, seorang laki-laki harus telah taat (kepada Allah) dan menjaga diri dari kerusakan pribadi." Jadi, pondasi agama sangat penting dalam membuat komitmen. Kewajiban ASI menjadi mudah direalisasikan jika masing-masing pihak telah mengetahui tupoksinya masingmasing.

Oleh karena itu, suami istri harus berhati-hatidan menjaga diri supaya tidak menjadi pengkhianat Allah. Akibatnya sangat berat. Status pengkhianat adakah kufur nikmat. Sebagai makhluk yang diberi banyak nikmat, harusnya berterima kasih. Jangan menunggu hati keras membeku sehingga petunjuk Allah tidak berguna lagi. Kalau Allah tidak suka, manusia akan diacuhkan, dan setan dibebaskan untuk menjadi teman setianya. Akhir episodenyadigiring masuk neraka. Alangkah ruginya hidup sengsara di dunia, di akhirat dihadiahi neraka (Q.S. [2]: 27, Q.S. [4]: 107, Q.S. [5]: 13, Q.S. [8]: 
56, 58, Q.S. [12]: 52, Q.S. [22]: 38, Q.S. [25]: 29, Q.S. [31]: 32, Q.S. [66]: 10).

Selain status khianat, ibu-ibu yang tidak bersedia memberikan ASI kepada bayinya adalah perusak. Ini adalah status yang kedua. Hal itu disebabkan zat kolostrum ASI yang luput diberikan kepada bayi. Dalam kolostrum, ada 19 komponen yang merupakan factor kekebalan anak dan factor pertumbuhan anak. Untuk factor kekebalan, bayi membutuhkan 12 komponen penting untuk membuatnya tetap sempurna. Sementara 7 komponen sisanya dibutuhkan untuk pertumbuhan jaringan saraf, otot, kulit, kolagen, dan tulang (B.R. Thapa, 2005: 579).

ASI bagi bayi merupakan sumber nutrisi. Komposisi ASI berbeda dan disesuaikan dengan kondisi bayi. ASI kolostrum mengandung antibodi yang sangat dibutuhkan bayi untuk menggantikan antibodi yang diperoleh dari ibu. Anti bodi dari ibu akan segera turun cepat sekali segera setelah bayi lahir. Bayiyang mendapat ASI akan lebih cerdas. Mengingat kecerdasan anak berkaitan erat dengan otak maka jelas perkembangan kecerdasan dipengaruhi oleh perkembangan otak. Faktor yang penting pada perkembangan otak adalah nutrisi yang diberikan (Helda, n.d: 195200).

ASI mengandung komposisi yang tepat dan menjadi makanan yang baik untuk bayi. Kandungannya terdiri dari proporsi yang seimbang dan cukup kuantitas semua zat gizi yang diperlukan untuk kehidupan 6 bulan pertama bayi (Kristiyanasari, 2011). ASI meningkatkan kecerdasan bagi bayi. Lemak pada ASI adalah lemak tak jenuh yang mengandung omega 3 untuk pematangan sel-sel otak sehingga jaringan otak bayi yang mendapat ASI Eksklusif akan tumbuh optimal dan terbebas dari rangsangan kejang hingga sel-sel saraf otak (Kristiyanasari, 2011).

Sebagai nutrisi, ASI dapat meningkatkan daya tahan tubuh bayi, mengembangkan kecerdasan, dan dapat meningkatkan jalinan kasih sayang (U. Roesli, 2005). ASI mengandung zat protektif bagi bayi. Seorang bayi yang mendapat ASI jarang menderita penyakit karena adanya zat protektif tersebut (Sunardi, 2008). Ibu yang memberikan ASI-nya akan turun risiko terjadinya pendarahan, anemia, terkena kanker. Jarak kehamilan menjadi jarang, rahim cepat mengecil, cepat langsing karena proses menyusui yang dilaksanakan segera dan eksklusif sampai dua tahun atau lebih.

Penelitian membuktikan bahwa anak-anak yang di masa bayinya mengkonsumsi ASI jauh lebih cerdas, lebih sehat, dan lebih kuat daripada anakanak yang di masa kecilnya tidak menerima asupan ASI (A.H Abdullah, 1993: 30). Bayi yang tidak mendapatkan ASI, hidupnya rentan sekali. Ketika November 2013 terjadi bencana topan Haiyan di Filipina, UNICEF dan WHO meminta para pihak yang terlibat untuk memprioritaskan pemberian ASI untuk menghindari penyakit dan kematian anak-anak. Setiap bayi yang lahir di daerah yang terkena dampak tidak boleh menkonsumsi apapun kecuali ASI, yang melindungi mereka dari infeksi yang mematikan("http://www.unicef.org/ind onesia/id/media_21914.htm," n.d.).

Dengan demikian, yang rusak itu tidak hanya bayinya saja, tapi ia merusak dirinya sendiri. Ketika ASI tidak 
disalurkan, seorang ibu akan potensial terkena kanker payudara (A.V. Holmes, Heather G. Jones, 2017). Penelitian menunjukkan bahwa ibu-ibu yang menyusui hingga dua tahun (lebih dari enam bulan) akan terlindungi dari kanker payudara (B. Cordeiro, 2014). Selain itu, ia akan dihadiahi dengan kehamilan yang sehat dari segi waktu. Setidaknya, ia akan terhindar dari kehamilan susulan selama proses menyusui. Itulah berkah bagi keluarga yang dengan senang hati menunaikan tugasnya.

Sesungguhnya, tugas penyusuan tidak semata-mata tanggung jawab ibu. Ayah (suami) juga harus mendukung terlaksananya tugas istri. Suami tidak hanya sekadar mencari dan memberikan nafkah ke istri dan keluarga, tapi sikap dan bahasa pun sangat menentukan. Sikap suami yang ramah dan suportif akan menenteramkan batin istri. Hal itu berpengaruh terhadap kemampuan istri dalam menjalankan tugas penyusuan. Secara psikologis, gesture dan bahasa suami akan mempengaruhi mood istri.

Sebagai pemimpin, suami harus berada di depan dalam contoh dan keteladanan. Suami harus yang paling awal dalam kebaikan, sehingga tertutup kemungkinan bagi istri untuk melakukan pembangkangan (nusyuz). Lebih baik jika setiap hari ada perencanaan dan evaluasi, tentang apa yang kurang, apa yang harus dilakukan, apa yang terlewatkan, dan Komitmen melakukan perbaikan. Seorang suami yang telah melakukan tugasnya, mengingatkan istri untuk menunaikan tugas ASI-nya, tapi diabaikan oleh istrinya, maka ASI adalah mutlak menjadi utang istri. Ini status yang ketiga.
Pandangan ini sejalan dengan sabda Rasulullah, "Jiwa seorang mu'min itu tertahan karena utangnya, sampai utang itu dilunasi" (al-Sulamiy, Juz III, t.t.: 393).

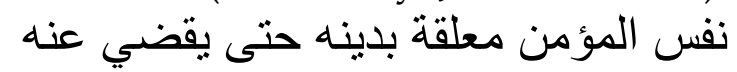

Hadits di atas harus dimaknai oleh hamba-Nya, bahwa kita semua berutang kepada Allah dalam bentuk ibadah. Firman Allah, "Aku tidak menciptakan jin dan manusia melainkan agar mereka beribadah kepada-Ku dengan ikhlas" (Q.S. Az-Zariyat [51]: 56) Manusia harus menaati-Nya semata-mata karena (menjalankan) agama, termasuk di dalamnya melaksanakan shalat dan menunaikan zakat (Q.S. [98]: 5). Istiqomah dalam shalat dan zakat akan menenteramkan keluarga, termasuk tugas istri dalam ASI.

Kita harus malu dengan pernyataan Allah, "Sesungguhnya Aku telah membeli dari orang-orang Mukmin, baik diri maupun harta mereka, dengan surga" (Q.S. AtTaubah [9]: 111). Utang manusia masih banyak, dan belum tentu terlunasi. Tapi Allah sudah memberikan kabar lain, yang seharusnya menggembirakan manusia. Di kehidupan dunia, komitmen pembelian itu sangat berharga. Komitmen itu bisa menjadi senjata dan modal untuk membuka usaha. Hanya saja, siapakah manusia yang siap berjuang di jalan Allah; bahkan bersedia sehingga terbunuh.

Jika manusia tidak melakukan perintah Allah, manusia berutang kepada Allah. Utang itu semakin bertumpuk, karena setiap hari nikmat Allah tidak pernah berhenti. Sejak bangun tidur, ketika Allah kembalikan ruh ke badan, hingga tidur kembali, nikmat Allah tidak akan bisa dihitung (Q.S. [14]: 34, Q.S. [16]: 18). Ketika seseorang tidak bisa tidur, dia akan stress. Artinya, nikmatnya sedang 
dihentikan. Dalam kajian Rahmanto (E. Rahmanto, 2016: 83-108). Utang merupakan suatu kewajiban dan janji serta ikatan yang harus diurai atau dilepaskan dengan cara melaksanakan atau memenuhi atau melunasi utang atau janji tersebut.

Manusia sudah berjanji kepada Allah (Q.S. [7]: 172) untuk memakmurkan dunia (Q.S. [11]: 61) bukan merusaknya (Q.S. [2]: 11-12). Status manusia adalah khalifah (Q.S. [2]: 30). Tugasnya mempromosikan, betapa kuasanya Allah, Maha Pengasih dan Maha Penyayang. Khalifah harus menjadi teladan dalam adil, baik memutuskan maupun menjalankan. Khalifah tidak boleh mengikuti hawa nafsu (Q.S. [18]: 28), karena iaakan tersesat dari jalan Allah, dan bisa menyesatkan lingkungan sekelilingnya. Ibu-ibu yang tidak welcome dengan ASI dan bayinya adalah ibu-ibu yang tersesat.

Manusia telah menerima berbagai nikmat dan kesempurnaan dari Allah SWT. Sungguh, Kami telah Menciptakan manusia dalam bentuk yang sebaik-baiknya (Q.S. [95]: 4). Kepada ibu bapak, janganlah membunuh anak-anakmu karena miskin. Kami-lah yang Memberi rezeki kepadamu dan kepada mereka; janganlah kamu mendekati perbuatan yang keji, baik yang terlihat ataupun yang tersembunyi. Ibu yang tidak memberikan ASI, sama dengan telah membunuh (sebagian potensi) bayinya (Q.S. [6]: 151).

Daripada menumpuk utang dan dosa, lebih baik berkonsentrasi melakukan pengabdian (Q.S. [98]: 5). Allah sedang menunggu pembuktian kita. Tentu, harus pengabdian yang terencana, supaya hasilnya diapresiasi. Semoga, sedikit demi sedikit, utangnya dilunasi. Utang kita bukan berupa uang, karena
Allah tidak membutuhkan uang. Sebaliknya, Allah SWT yang akan menggelontorkan uang, untuk membayar utang. Sebelum uang datang, tunaikan ASI bayi, supaya ibu-ibu tidak berutang. Bagi suami, dukung ibu si bayi, dengan moril dan meteril.

Sebagai makhluk, manusia harus tunduk kepada penciptanya. Dialah yang telah memberi "makanan" kepada manusia untuk menghilangkan lapar dan mengamankan dari rasa ketakutan (Q.S. [106]: 4). Dengan mengikuti petunjuk dari Allah, perjalanan manusia akan dimudahkan. Dua tahun penyusuan bukanlah beban, justru mempertahankan kesempurnaan. Semuanya (ibu, bayi, ayah) akan mendapatkan keberkahan. Yakinlah, berkah yang terbaik adalah ketenangan dalam keimanan (Q.S. [48]: 4).

Sebagai imam, suami harus memulai dari dirinya sendiri (al-Qusyairiy, no. 2360, III/78). Sebelum menuntut kelayakan dari istrinya, ia yang harus memenuhi kelayakan dirinya. Suami harus sudah selesai dengan dari permasalahan substantif terkait pikiran, sikap, dan perilaku pribadinya. Indikasinya, lembut dalam ucapan, serta istiqomah dalam perbuatan. Artinya, tuntutan kaaffah itu sudah dibuktikan dalam tindakan keseharian.

Sebagai leader, suami harus menjadi yang terdepan dalam berbagai hal. Ia harus bisa membawa gerbong keluarga menuju surga. Apalagi berhadapan dengan derasnya ancaman budaya global. Penempatan posisi suami sebagai leader sejati akan menahan pengaruh dari promosi gender terhadap istrinya. Kekuatannya sebagai laki-laki, yang kuat, jantan, rasional, perkasa; harus dikombinasikan dengan kekuatan lemah 
lembut, cantik, emosional, dan keibuan perempuan (N.Z. Situmorang, 2011: 129135).

Sebagai teladan, sifat qawwan harus menjadi dasar dan jiwa dalam kepemimpinan keluarga. Suami adalah penanggungjawab, penguasa, pemimpin, penjaga atau pelindung (M. Sai, 2015: 5776). Suami harus merealisasikan kelebihan-kelebihannya dalam membawa keluarga menjadi sakinah dunia dan akhirat. Ia harus berterima kasih kepada Allah atas kelebihan penalarannya, kesempurnaan akalnya, kejernihan pikirannya, kematangannya dalam perencanaan, keteguhan tekadnya, sehingga keluarga menjadi ladang beramal kepada Allah swt.

Suami membuka diri, melakukan identifikasi, termasuk membimbing istrinya supaya mempersiapkan diri. Satu hal penting yang harus dimusyawarahkan adalah pentingnya membersihkan hati dan pikiran dari kotoran, kemudian bersama-sama secara ragawi memelihara diri supaya tidak ada kendala dengan kelahiran bayi, dan produksi ASI. Insya Allah, jika rutenya sejalan, metodenya bersifat keteladanan, pasti akan tiba di tempat tujuan, yaitu Ridla Allah SWT (Q.S. [16]: 125).

Dengan kelayakan di atas, suami akan mudah membawa istrinya terhindar dari ketiga status di atas. Dengan izin Allah swt., istrinya akan terhindar dari status pengkhianat syari'at, dari status perusak diri dan anak-anaknya, dan dari utang ASI kepada anak-anaknya. Ketika mereka berdua sedang berikhtiar untuk dipercaya anak, maka pengetahuan dan pemahaman tentang ASI adalah bagian penting dari ikhtiar tersebut. Jadi, tidak ada lagi kejadian anak ditinggal ASI oleh ibunya.

\section{PENUTUP}

ASI adalah hak bayi yang harus ditunaikan oleh orang tuanya. Apakah langsung dari ibu kandungnya atau dari ibu susuan yang bersedia memenuhi hak itu. Ahli kesehatan dunia telah meneliti dan menyepakati bahwa air susu ibu tidak tergantikan. Bayi yang tidak mendapatkan asupan ASI memiliki resiko yang cukup besar terkait kelangsungan hidupnya. Bayi yang terabaikan hak asinya akan rentan dari berbagai virus dan penyakit. Itulah mengapa Allah SWT. memerintahkan para Ibu untuk menunaikan hak ASI bayi, untuk kesempurnaan, selama dua tahun.

Status hukum ibu-ibu yang tidak menunaikan tugas ASI-nya ada tiga. Pertama, mereka khianat terhadap amanah Allah SWT. Kedua, mereka merusak dirinya sendiri, juga menghambat perkembangan bayinya secara sempurna. Ketiga, mereka berutang kepada Allah dalam bentuk pengabdian (ibadah), berutang juga kepada bayinya dalam kolostrum dan ASI. Hutang itu tidak akan bisa dibayar sampai meninggalkan dunia.

Sebagai solusi, harus diintensifkan pendidikan berkeluarga, mulai dari ruang keluarga, dan dimulai oleh suami, sebagai pemimpin keluarga, kepada dirinya sendiri. Suami harus menjadi imam yang baik supaya ditaati ma'mumnya. Suami harus menjadi leader yang mumpuni, supaya gerbongnya bergerak sesuai arah syari'at. Suami harus menjadi teladan yang baik, karena qawwam adalah prasyarat dari Allah swt. untuk suami 
dalam membentuk dan memimpin keluarga.

Suami harus membantu istri menggali pengetahuan dan panduan syariat tentang pentingnya ASI. Untuk lebih merasionalkan syariat tersebut, perlu membuka kajian pakar kesehatan tentang ASI. Insya Allah akan diperoleh solusi. Suami harus membuka diri, melakukan identifikasi, termasuk membimbing istrinya supaya mempersiapkan diri. Setelah ada bayi, suami harus mendukung ibu si bayi secara moril dan meteril.

\section{DAFTAR KEPUSTAKAAN}

Abdullah, A.H. 1993. Keutamaan Air Susu Ibu. Jakarta: Fikahati Aneska.

Al-Kalam. 2009. versi 1.0. Bandung: Dipenogoro.

al-Sijistany, A.D.S. n.d. Sunan Abu Dawud.. Beirut: Daar al-Fikr, Juz II.

al-Qusyairy, M.H.M. n.d. Pentahqiq: Muhammad Fuad 'Abd al-Baaqiy. Beirut: Daar Ihya al-Turots al-'Arabiy, Juz IV.

Ariani. 2009. Ibu Susui Aku: Bayi Sehat dan Cerdas dengan ASI. Bandung: Khasanah Intelektual.

A.V. Holmes, Heather G. Jones, dan B. C. C. 2017. Breasfeeding and Cancer Prevention, EmergingIssues Brief, New Hampshire Comprehensive Cancer Collaboration.

az-Zuhaili, W. 2013. Tafsiral-Munir. Penerjemah: Abdul Hayyie al Kattani, dkk. Jakarta: Gema Insani, Jilid 1.

Bek, M.Kh. 1989. Nuruul Yaqiin fii Shirati Sayyid al-Mursalin. Bandung: Sinar
Baru.

Biancuzzo, M. 1999. Breastfeeding the Newborn: Clinical Strategies for Nurses. Michigan: Mosby.

Cordeiro,B. 2014. Breasfeeding lowers your breast cancer risk. Retrieved from www.mdanderson.org

Departemen Kesehatan RI. 1991. Buku Panduan Manajemen Laktasi. Jakarta: Direktorat Gizi Masyarakat.

Haikal, Muhammad. 1993. Sejarah Hidup Muhammad. Penerjemah: Ali Audah. Bogor: Litera AntarNusa, cet. XVI.

Harahap. 2014. Penelitian Kepustakaan. Iqra', 8(1).

Helda. n.d. Kebijakan Peningkatan Pemberian ASI Eksklusif. KESMAS, 3(5).

Hockenberry, M.J. and David Wilson. 2015. Wong's Nursing Care of Infants and Children. St. Louis Missouri: Elsevier Mosby.

http://www.unicef.org/indonesia/id/m edia_21914.htm. (n.d.).

http:/ / www.who.int/mediacentre/event s/2016/world-breastfeedingweek/en/. (n.d.).

Kristiyanasari. 2011. ASI, Menyusui $\mathcal{E}$ SADARI. Yogyakarta: Nuha Medika.

Mataram, I.K.A. 2011. Aspek Imunologi Air Susu Ibu. Ilmu Gizi, 2(1).

Moleong, L.J. 2011. Metode Penelitian Kualitatif. Bandung: Remaja Rosdakarya.

Peraturan Pemerintah No. 33 Tahun 2013 tentang Pemberian Air Susu Ibu Eksklusif. 


\section{Status Hukiun Ituı Tidak Menunısui Bayii dan Solusi Pencengahanninga || 231}

Raco, J.R. 2010. Metode Penelitian Kualitatif: Jenis, Karakteristik dan Keunggulannya. Jakarta: Grasindo.

Rahmanto, E. 2016. Kewajiban Seorang Mukmin Melunasi Utang: Studi Ma`Ani Alhadith. Al-A'raf, XIII(1).

Roesli, U. 2005. Mengenal ASI Eksklusif. Jakarta: Trubus Agriwidya.

Sai, M. 2015. Kesetaraan dan Ketaksetaraan Laki-laki dan Perempuan: Kajian al-Qur'an Surat al-Nisa. Qawwam, 9(1).

Simanjuntak, B.A dan Soedjito Sosorodiharjo. 2014. Metode Penelitian Sosial. Jakarta: Yayasan Pustaka Obor Indonesia.

Sitompul, E.M. 2014. Dahsyatnya Gerakan Shalat untuk Ibu dan Janin. Jakarta: Publishing Langit.
Situmorang, N.Z. 2011. Gaya Kepemimpinan Perempuan. In Proceeding PESAT. Depok: Universitas Gunadarma.

Soetjiningsih. 1997. ASI Petunjuk untuk Tenaga Kesehatan. Jakarta: EGC.

Sunardi. 2008. Variasi Makanan Bayi. Jakarta: Gramedia.

Thapa, B.R. 2005. Health Factors in Colostrum. Indian Journal of Pediatrics, 72.

www.who.int. (n.d.).

Yuliarti, N. 2010. Keajaiban ASI: Makanan Terbaik Untuk Kesehatan, Kecerdasan dan Kelincahan si Kecil. Yogyakarta: Penerbit ANDI. 